\title{
Valuation of Transport Service Characteristics Relevant for the Establishment of Fast Inter-City lines in Sea-Borne Passenger Traffic
}

\author{
Maja Krčumª, Veljko Plazibata, Senka Šekularac Ivoševićb
}

This paper analyses and evaluates major characteristics of transport services relevant for the organization of fast inter-city lines in maritime passenger transport. Service characteristics that have been subjected to research and assessment include: 1) individual travel costs, 2) travel duration, 3) travel safety, 4) social costs of transport, 5) ability to create a traffic service and 6) other elements of the traffic service. Using descriptive statistics and growth matrix, the analysis reveals that the Ability to create a traffic service and Travel duration, both having direct growth rates of $75 \%$, will have the largest impact on the establishment of fast inter-city sea-borne lines, followed by the Social costs of transport with the direct growth rate of $68.42 \%$. The impact of other transport service characteristics on the organization of fast inter-city lines in maritime passenger transport is estimated as moderate.

\section{KEY WORDS}

$\sim$ Maritime passenger transport

$\sim$ Transport services

$\sim$ Fast vessel inter-city lines a. University of Split, Faculty of Maritime Studies, Split, Croatia e-mail: mkrcum@pfst.hr

b. University of Montenegro, Faculty of Maritime Studies, Kotor, Montenegro e-mail: senkas@ac.me

doi: 10.7225/toms.v07.n02.007

This work is licensed under (cc) BY

\section{INTRODUCTION}

The transport and maritime policies of the Republic of Croatia contain strategic development guidelines that rather loosely define the need to strike a balance between different transportation systems, which is necessary for the improvement of the transport network, traffic safety, environmental conditions, travel duration and, in particular, given the fact that Croatia has become a full member of the European Union in which finding a balance between traffic modes is one of key transport policy objectives. Europe's maritime interests mostly revolve around the welfare, prosperity and security of its citizens and communities (Moise, 2015). In this respect, Croatia's efforts to introduce intercity maritime transport are insufficient in cargo trade and very poor in passenger traffic, although the latter is deemed to have great potential. The establishment of fast sea-borne passenger traffic along Croatia's coastline would considerably relieve road traffic and contribute to the realisation of the objectives of transport and maritime policies, especially in case of active introduction of short-haul routes which are crucial for a better valuation and usage of sea for transportation. Maritime transportation, similar to land and air transportation, unfolds in its own space, which is simultaneously geographical by its physical attributes, strategic by its control and commercial by its usage. While geographical considerations tend to be constant in time, strategic and especially commercial considerations are much more dynamic (Serap and Guler, 2007). The organisation of fast coastal inter-city runs in the framework of the national maritime and traffic system would contribute to the improvement of the traffic system 
across the nation and generate a number of benefits which would balance different modes of transport. Although maritime infrastructural framework exists (fairways, seaports), there is a lack of quality entrepreneurial concepts which would allow the existing potentials to be realized. One of possible concepts is the introduction of fast inter-city passenger vessels.

In this respect, the main purposes of this study are the analysis of the basic characteristics of the transport service in sea-borne passenger traffic, and the scientific examination of the information and insights obtained to assess the importance of these characteristics for the establishment of fast inter-city passenger vessels in Croatian coastal waters. The research, formulation and presentation of research results in this paper are based on scientific methods, including analysis and synthesis, abstraction and concretisation, descriptive statistics and growth matrix as one of the valuable tools for the evaluation of the transport service characteristics relevant for the organization of fast inter-city lines in maritime passenger transport in the Republic of Croatia.

\section{THEORETICAL FRAMEWORK}

According to the World Tourism Organization (Tourism highlights, Madrid, 2011), road transport accounts for $51 \%$ of international tourist arrivals. As for Croatia, the road share in tourist transport is considerably higher: around 70 per cent of foreign tourists come to Croatia by road (Jurčević, Madunić, Tolušić, 2006). The road transport share in tourism is somewhat lower along the shores of Dalmatia where three international airports (Zadar, Split and Dubrovnik) operate on a year-round basis, but the share of sea-borne transport remains marginal in all aspects (Kovačić and Milošević, 2016). Given the fact that Croatia's Gross Domestic Product (GDP) heavily depends on tourism, with travel and tourism directly contributing with $10 \%$ and indirectly to over $23 \%$ in 2015 and expected to increase to $30 \%$ by 2026 (World Travel \& Tourism Council, 2016), with most of the growth expected on the coastline and islands, the current predominance of road transport in Croatia is obviously not sustainable in the long run. The existing situation and forecasts require the defining and implementation of a proactive traffic and shipping policy aimed at reducing the share of road traffic, particularly toward and around major coastal tourist destinations. Slight changes are already taking place. The analysis of passenger transport trends in Croatia has confirmed that sea-borne passenger transport has been increasing slowly but almost steadily over the years (Pupavac et al., 2015). The growth was halted only during the Homeland War (1991-1995) and slowed down during the recent global economic crisis that deeply affected the country (Figure 1).

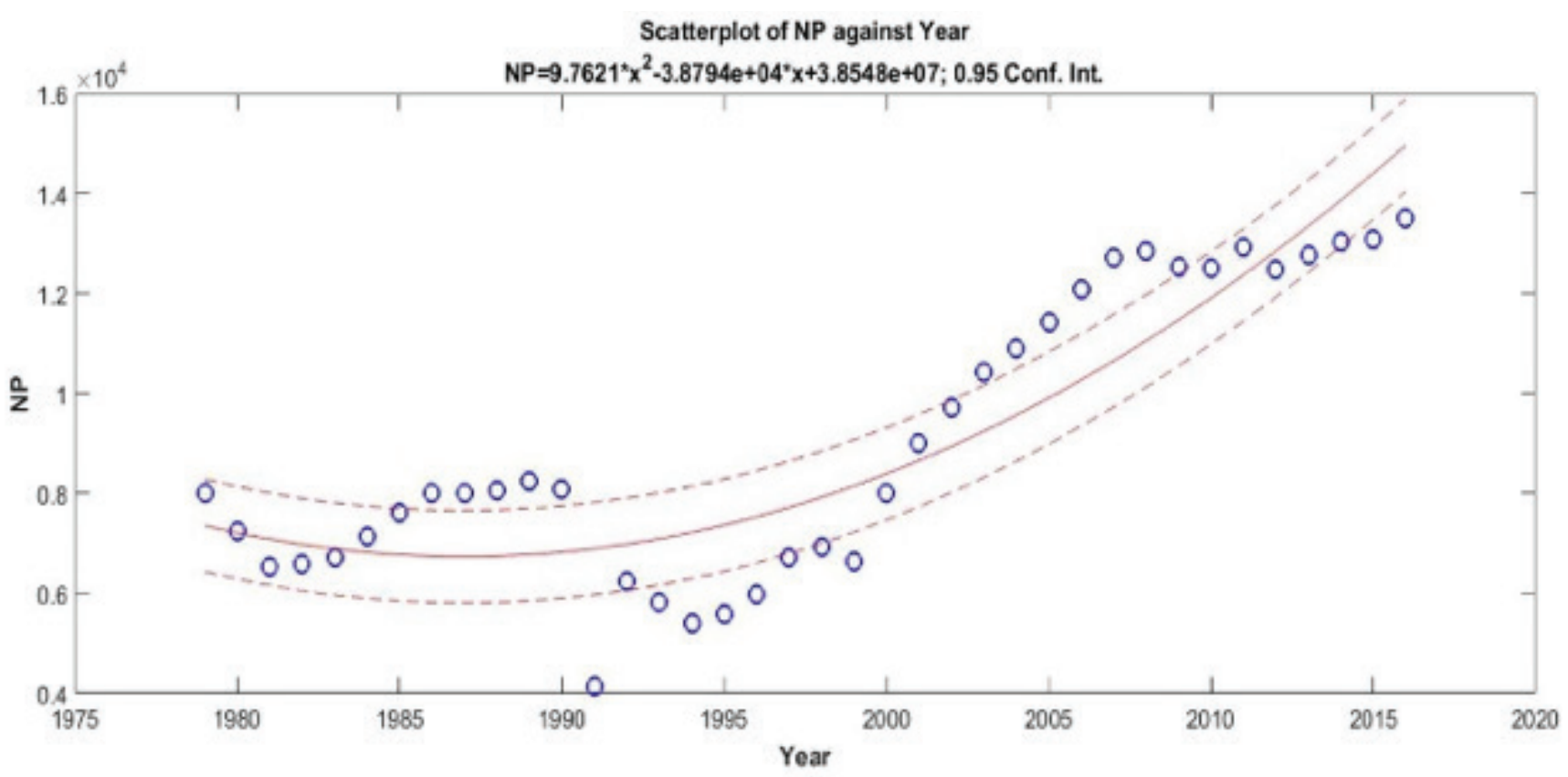

Figure 1.

Number of passengers served by Croatian seaports 1979 - 2013 (Source: authors, according to Statistical Yearbook of the Republic of Croatia, various years). 
A short descriptive analysis (cf. Table 1) indicates that Croatian sea ports served $343,843,000$ passengers over the observed period, i.e. the average of $9,048,500$ passengers per year (SD: 2,808,600).

The lowest number of passengers transported in Croatian maritime passenger traffic in the observed period was 4,138 million passengers in 1991, while the largest number of passengers were carried in 2013 when 13,11 million passengers were transported. The analysis has confirmed both the continuous interest of users and the stamina of sea-borne passenger transport in Croatian waters.

Table 1.

Descriptive analysis of passenger traffic in Croatia's seaports from 1979 to 2013

\begin{tabular}{ll} 
& No. of passengers \\
\hline MEAN case 1-35 & $9,048.5$ \\
\hline MEDIAN case 1-35 & 8,040 \\
\hline SD case 1-35 & $2,808.6$ \\
\hline VALID_N case 1-35 & 38 \\
\hline SUM case 1-35 & 343,843 \\
\hline MIN case 1-35 & 4,138 \\
\hline MAX case 1-35 & 13,525 \\
\hline
\end{tabular}

The figures can be improved further by establishing fast passenger shipping routes along the coastline. In this way, sea shipping companies would contribute to the implementation of the objectives of the national traffic and maritime policies and considerably boost Croatia's passenger shipping and maritime economy in general. Sea-borne coastal services would positively affect the national maritime and traffic system in terms of traffic mode balance. The existing system of sixteen fast passenger lines that connect coastal cities with the islands experiences a continuous increase in passenger turnover. It is therefore reasonable to assume that further development of similar inshore services would bring new benefits to the nation's traffic system (Sabolović, 2002). Further development of fast passenger shipping service may also result in a more adequate evaluation of maritime passenger transport as an alternative to road transport along the eastern Adriatic coast. As a result, passenger transport flow would be redirected from the mainland to the sea, facilitating the introduction of new modes and forms of transport. Benvenuto et al (1996) propose the introduction of a new sea passenger line serviced by innovative high speed vessels (SES) in the metropolitan area round Genoa. Chen et al (2017) point out that urban ferry system can carry a large number of travellers, which may alleviate the pressure on road traffic.
According to them, service time reliability plays an essential part in attracting travellers to the ferry system.

The implementation of a fast inter-port passenger service seems to be a sound strategic move both in national and international sea-borne passenger traffic. In national waters, this would imply the networking of coastal towns that have developed around important seaports: Pula, Rijeka, Zadar, Šibenik, Split, Ploče and Dubrovnik. Fast passenger liners could further connect these towns with major tourist destinations such as Rovinj, Poreč, Biograd, Makarska and other towns during tourist season. This would clearly increase the spatial mobility of tourists and local population and reduce the seasonality of Croatia's maritime passenger transport. As for international transport, fast lines between the above mentioned Croatian ports and the coastal towns in Italy, Montenegro, Albania and Slovenia should be established. The establishment of these fast lines would have an economic multiplier effect, as it would contribute to further integration of Croatia with the European Union and facilitate the accession of Montenegro and Albania to the European Union.

The assessment of the economic justifiability of the establishment of fast vessel passenger lines requires factors affecting passenger traffic flows, such as (Pupavac, 2009): 1) demographic factors, 2) the standard of living, 3) tourist sojourn, 4) institutional features, 5) size, type and spatial distribution of production and trade centres, 6) voyage time in maritime passenger transport, and 7) individual costs in maritime passenger transport to be defined. Then, essential transport service characteristics through which users access a specific mode of transport and which are, simultaneously, suitable for evaluation using the growth matrix need to be defined. Five major characteristics have been obtained (Plazibat et al., 2015), as follows: Individual travel costs, Travel duration, Transport safety, Social costs of transport, and Ability to create a traffic service.

\section{METHODOLOGICAL APPROACH}

A scientifically established assumption implies that the transport service in sea-borne passenger traffic consists of " $n$ " inter-reliant characteristics (elements). The value (e.g. an input) of an $i$ characteristic of the maritime passenger transport service $(\mathrm{i}=1, \ldots, \mathrm{n})$ is expressed as $y_{i t}$ and $y_{i, t-1}$ during the periods $t$ and $t-1$. A growth of the input value of the $i$ characteristic of the maritime passenger transport service is expressed as:

$\Delta y_{i t}=y_{i t}-y_{i t-1}$

An indirect growth rate of the $i$ characteristic of the maritime passenger transport service, in relation to $j$, is defined as relation between the input growth of the $i$ characteristic of the sea-borne passenger transport service $\Delta y_{i t}$ and the input value of the $j$ characteristic of the maritime passenger transport service: 
$r_{i j t}=\frac{y_{i t}}{y_{j t}} \quad i, j=0, \ldots, n \quad y_{j t} \neq 0$

The indirect growth rates can be expressed as a growth matrix that is based on the values of the transport service characteristics in the sea-borne passenger transport (Stojanović, 1999):

$R_{t}=\left[\begin{array}{lrlr}r_{11} & r_{12} & \ldots & r_{1 n t} \\ r_{21} & r_{22} & \ldots & r_{2 n t} \\ \ldots & \ldots & \ldots & \ldots \\ r_{n 1 t} & r_{n 2 t} & \ldots & r_{n n t}\end{array}\right] t=1, \ldots, T$

where the elements on the main vertical refer to direct growth rates $(i=j)$, while the others refer to indirect growth rates $(i \neq j)$. The elements in the $i$ row refer to the input growth in the $i$ characteristic of the transport service in sea-borne passenger traffic in relation to the values of other characteristics. The items in the $i$ column refer to the growth of the input value of all characteristics of the sea-borne passenger transport service during the period $t$. Therefore, every characteristic of the sea-borne passenger transport service in the growth matrix is represented by one row and one column, with elements expressing indirect or relative growth relationships. For example, the first row indicates the input growth of the first characteristic of the sea-borne passenger transport service in relation to other characteristics, whereas the first column indicates the growth of the remaining characteristics of the maritime passenger transport service in relation to the input of the first characteristic of the transport service in sea-borne passenger traffic. The remaining rows and columns refer to the remaining transport service characteristics of the sea-borne passenger transport.

The indirect growth rates can be described with regard to the inputs of the $j$ characteristic of the maritime passenger transport service in the period $t=1$ :

$r_{i j t}^{\prime}=\frac{\Delta y_{i t}}{\Delta y_{j, t-1}} \quad i, j=0, \ldots, n$

The connection between indirect growth rates (2) and (4) can be established through the following inter-relations:

$\left.\begin{array}{l}r_{i j t}=r_{i j t}^{\prime} / 1+r_{j j t}^{\prime} \\ r_{i j t}^{\prime}=r_{i j t} / 1-r_{j j t}^{\prime}\end{array}\right\} \quad i, j=1, \ldots, n$

The growth matrix can be determined through the external vector of the characteristics of the maritime passenger transport service (Zelenika and Pupavac, 2008). This way of determining the matrix is useful in practical calculation of its growth. The vector describing the growth of the transport service characteristics' values in the sea-borne passenger transport can be expressed as:

$\Delta y_{i t}=\Delta y_{1 t}, \ldots, \Delta y_{m t}$

The vector of the reciprocal values of the maritime passenger transport service characteristics is defined as:

$\left(\frac{1}{y_{t}}\right)=\left(\frac{1}{y_{1 t}}\right), \ldots,\left(\frac{1}{y_{n t}}\right) \quad i, j=0, \ldots, n \quad y_{i t} \neq 0$

The growth matrix of the values of sea-borne passenger transport service characteristics is defined by the external value of the growth vector and of the vector of the reciprocal values of the maritime passenger transport service characteristics (Stojanović, 1990).

$R_{p t}=\Delta y_{t}^{\prime} \frac{1}{y_{t}}=\left[\begin{array}{c}\Delta y_{1 t} \\ \vdots \\ \Delta y_{m t}\end{array}\right]\left(\frac{1}{y_{1 t}}, \ldots, \frac{1}{\Delta y_{n t}}\right)$

$R_{p t}=\left[\begin{array}{ccc}\frac{\Delta y_{1 t}}{y_{1 t}} & \cdots & \frac{\Delta y_{1 t}}{y_{n t}} \\ \dddot{\Delta y_{m t}} & \cdots & \frac{\Delta y_{m t}}{y_{n t}}\end{array}\right]\left[\begin{array}{ccc}r_{11 t} & \cdots & r_{1 n t} \\ \cdots & \cdots & \cdots \\ r_{m 1 t} & \cdots & r_{m n t}\end{array}\right]$

If only direct growth rates are analysed, the growth of one characteristic of the transport service in sea-borne passenger traffic is expressed independently from the growth of the others. On the other hand, when analysing indirect growth rates, i.e. the growth of the $i$ characteristic of the transport service in seaborne passenger traffic in relation to $j(\mathrm{i}, j=1, \ldots, \mathrm{n})$, the structure of the growth of the importance of the characteristics can be determined and all relationships across the system expressed by the growth matrix.

If direct and indirect rates are expressed simultaneously, the changes of values of transport service characteristics in maritime passenger traffic, and their structural relationships can both be feasibly traced.

\section{RESEARCH RESULTS AND DISCUSSION}

The starting point in the evaluation of the importance of maritime service characteristics was 2008, when the "regular" seasonal fast line Pula - Zadar was established as a symbol 
of the idea of organization of fast inter-city routes in maritime passenger traffic. For the initial period (2008) the importance of the individual characteristics of maritime transport service was evaluated and rated by a value (index), i.e. by an input the value of which was assessed from a broader social viewpoint. After that, the growth of inputs for each characteristic of maritime transport service was anticipated for the year 2016. Finally, forecasts for the year 2025 were drawn up. The first observed period (20082016) was defined as the period when the idea of introducing inter-city passenger lines along Croatia's shores was developed. Although the period lasted eight years, it was not observed in the traditional context of long-term planning. Instead, it was rather observed as the period of exploration and introduction of fast sea-borne passenger lines in coastal inter-city traffic. The eight-year period was considered a reasonable timeframe to obtain insights into all benefits of introduction of inter-city lines in maritime passenger traffic before the complete liberalisation of the sea-borne passenger market. The next period (2016-2025) is anticipated to see not only the establishment of fast sea-borne passenger lines along Croatia's shores, but also the maturity of these products / services in terms of economic and social impacts.

The valuation of major characteristics of maritime transport service to quantify their influence on the organisation of fast seaborne passenger lines, was performed as follows:

\section{Safety in sea-borne passenger transport.}

Maritime passenger transport is indisputably the safest mode of passenger transport. Accordingly, this element for 2008 is allocated a relatively high rated input of 60 . As this characteristic of the transport service is insufficiently utilised, it is expected that the users will increasingly recognise this characteristic, i.e. that it will become increasingly important in the long run. Therefore, this characteristic of the transport service has a rated input of 90 for the year 2025 .

\section{Travel duration.}

In maritime passenger transport, travel duration is a function consisting of three elements: 1) waiting time, 2) network access time, and 3) speed at sea. Overall travel duration is an exceptionally important characteristic of the transport service. This has been confirmed by the introduction of fast liners running between Croatia's inhabited islands and coast since 2000. However, the project has never evolved and has never been extended to meet the transportation needs along the coastline. Therefore, travel duration as a transport service characteristic for 2008 is allocated a relatively low rated input of 30. Since full valuation of the benefits of fast vessel inter-city lines for the reduction overall travel duration will result in increased importance of this characteristic, its rated input for 2025 is 80 .

\section{Individual travel costs in maritime passenger transport}

Passenger's individual costs in maritime transport represent a complex function that includes expenses such as travel fares, access costs, parking charges, luggage transport fees, and added service costs. In terms of costs, sea-borne passenger traffic is very competitive in comparison with bus transport service. However, this is also one of the insufficiently evaluated transport service characteristics. There is a lack of inter-city routes in maritime transport and the sailing schedule is not adapted to tourist demand. These are the reasons for allocating a rated input of 50 to this transport service characteristic for 2008, whereas its rated input for 2025 is 85 , when fast passenger inter-city coastal lines are expected to be fully established.

\section{Social costs of transport in maritime passenger transport}

Social costs are part of the total cost of maritime transport on the sailing route. These costs primarily refer to the construction of infrastructure as these investments are huge and produce a very slow rate of return, which makes all incentives for maritime infrastructure development economically justified. Since these costs have been largely ignored by various transport analyses, it is no surprise that a number of benefits of sea-borne passenger transport, compared to other forms of transport, have been bypassed. This is why the rated input of 30 was allocated to this transport service characteristic for 2008. Full EU membership allows Croatia to develop a better transport policy focusing on the sustainable development of transport, i.e. on the reduction of the social costs of transport and encouraging sea-borne passenger traffic. In this sense, this maritime transport characteristic has an exceptionally high rated input of 95 for the year 2025 .

\section{Ability to create maritime traffic service.}

The ability of local shippers to create traffic services in the inter-city liner trade is rated with the lowest input of 20 for the year 2008. This poor rating can be attributed to the lack of appropriate fast vessels and the shippers' lack of vision and proactive policy with regard to impending changes in the national passenger market. The threat of competitors from the European Union is expected to increase the ability of Croatian shippers to create transport service, i.e. the overall readiness, flexibility, and capacity to maintain sailing schedules is expected to grow. Hence, this characteristic of the transport service has the rated input of 80 for 2025. A substantial growth of this input is also expected given the fact that fast vessels of 50-60 $\mathrm{m}$ in length carrying around 500 passengers have good sailing performance in typical sea conditions, in particular during winter, when the conditions commonly include fresh breeze (5 Bf) and rough seas (3-4 m). 


\section{Other elements}

Other elements of maritime traffic service include: seaports and passenger terminals, human resources and information technologies, which largely contribute to the quality of service in sea-borne passenger traffic. Recognising the importance of seaports in national and international passenger traffic, state and local authorities have completed or have been completing port infrastructure modernization projects, particularly in the ports of Rijeka, Ploče, Dubrovnik, Split, and Gaženica near Zadar. It is indisputable that Croatia's seaports are not an obstructing factor in the organization of fast passenger liner trade in maritime transport. The proficiency of human resources at all levels of maritime education, maritime tradition and the developed systems of sea shipping management ensure the provision of high-quality services. For these reasons, the rated input for this maritime transport characteristic is 60 for 2008, and 90 for 2025.

The results of the analysis of the relevant characteristics of the maritime passenger transport service are presented in Table 2.

Table 2.

Value of the characteristics with regard to the organization of fast inter-city routes.

\begin{tabular}{|c|c|c|c|c|c|}
\hline \multirow[t]{2}{*}{ No. } & \multirow[t]{2}{*}{$\begin{array}{l}\text { Characteristics of the service in maritime } \\
\text { passenger traffic }\end{array}$} & \multicolumn{3}{|c|}{ Inputs $Y_{i t}$} & \multirow{2}{*}{$\begin{array}{l}\text { Growth } \\
\Delta \mathrm{y}_{\mathrm{i}^{\prime}} 2025\end{array}$} \\
\hline & & 2008 & 2016 & 2025 & \\
\hline 1. & Transport safety & 60 & 70 & 90 & 30 \\
\hline 2. & Travel duration & 30 & 50 & 80 & 60 \\
\hline 3. & Individual travel costs & 50 & 60 & 85 & 35 \\
\hline 4. & Social costs of transport & 30 & 55 & 95 & 65 \\
\hline 5. & Ability to create the traffic service & 20 & 45 & 80 & 60 \\
\hline 6. & Other elements & 70 & 80 & 90 & 20 \\
\hline
\end{tabular}

The information presented in Table 2 facilitate the creation of the growth matrix for the characteristics of maritime passenger transport service with reference to the current and future values for the period 2008-2025.

The vector of growth of the characteristics of service in maritime passenger transport is:

$\Delta Y_{2025}^{\prime}=\left[\begin{array}{l}30 \\ 60 \\ 35 \\ 65 \\ 60 \\ 20\end{array}\right]$

The vector of the reciprocal values of the characteristics of service in maritime passenger transport is:

$\frac{1}{Y_{2025}}=\left[\frac{1}{90}, \frac{1}{80}, \frac{1}{85}, \frac{1}{95}, \frac{1}{80}, \frac{1}{90}\right]$
The product of the external vector $\Delta Y^{\prime}{ }_{2025}$ and $1 / Y_{2025}$ determines the growth matrix for the characteristics of maritime passenger transport service with reference to the current and future values.

The growth matrix of the importance of maritime passenger transport service characteristics as model elements of inter-city passenger traffic route organization was derived from calculation results, with reference to the current and future values for the period 2008 - 2025 (cf. Table 3).

The research conducted and the valuation of the characteristics of maritime passenger transport service as elements of inter-city passenger traffic route organization model have produced direct growth rates of individual characteristics as the model elements (Figure 2).

Figure 2 clearly shows that, in the upcoming period, all the characteristics of services in sea-borne passenger traffic as model elements of inter-city passenger traffic line organization should achieve considerable growth rates, which would allow national shippers to cope with foreign competitors, including those operating in other modes of transport.

Direct growth rates of the characteristics of services in maritime passenger traffic as model elements of inter-city passenger traffic line organization can be divided into two main groups. 
The first group consists of the ability to create sea-borne passenger traffic service and travel duration, both having direct growth rates of $75 \%$, and the social costs of transport with the growth rate of $68.42 \%$. The impact of these characteristics as model elements of inter-city passenger traffic line organization can be assessed as markedly strong.

The other group of characteristics includes individual travel costs with the growth rate of $41.18 \%$, transport safety with the growth rate of $33.33 \%$, and other elements ( $25 \%$ ). The impact of these characteristics as model elements of inter-city passenger traffic line organization can be assessed as moderately strong.

Indirect growth rates of the characteristics of services in sea-borne passenger traffic as the model elements of inter-city passenger traffic line organization can also be anticipated from results presented in Table 2 .

Table 3.

Growth rates of the importance of characteristics over the period 2008-2025.

\begin{tabular}{|c|c|c|c|c|c|c|}
\hline & Safety & $\begin{array}{l}\text { Travel } \\
\text { duration }\end{array}$ & $\begin{array}{l}\text { Individual } \\
\text { costs }\end{array}$ & Social costs & $\begin{array}{l}\text { Ability to create } \\
\text { tr. service }\end{array}$ & $\begin{array}{l}\text { Other } \\
\text { elements }\end{array}$ \\
\hline Safety & $\begin{array}{l}30 / 90= \\
0,333333= \\
33,33 \%\end{array}$ & $\begin{array}{l}30 / 80= \\
0,375= \\
37,50 \%\end{array}$ & $\begin{array}{l}30 / 85= \\
0,352941= \\
37,50 \%\end{array}$ & $\begin{array}{l}30 / 95= \\
0,315789= \\
31,58 \%\end{array}$ & $\begin{array}{l}30 / 80= \\
0,375= \\
37,50 \%\end{array}$ & $\begin{array}{l}30 / 90= \\
0,3333= \\
33,33 \%\end{array}$ \\
\hline Travel duration & $\begin{array}{l}60 / 90= \\
0,666667= \\
66,67 \%\end{array}$ & $\begin{array}{l}60 / 80= \\
0,75= \\
75,0 \%\end{array}$ & $\begin{array}{l}60 / 85= \\
0,7059= \\
70,59 \%\end{array}$ & $\begin{array}{l}60 / 95= \\
0,631579= \\
63,16 \%\end{array}$ & $\begin{array}{l}60 / 80= \\
0,75= \\
75,0 \%\end{array}$ & $\begin{array}{l}60 / 80= \\
0,75= \\
75,0 \%\end{array}$ \\
\hline Individual costs & $\begin{array}{l}35 / 90= \\
0,388889= \\
38,89 \%\end{array}$ & $\begin{array}{l}35 / 80= \\
0,4375= \\
43,75 \%\end{array}$ & $\begin{array}{l}35 / 85= \\
0,411765= \\
41,18 \%\end{array}$ & $\begin{array}{l}35 / 95= \\
0,368421= \\
36,84 \%\end{array}$ & $\begin{array}{l}35 / 80= \\
0,4375= \\
43,75 \%\end{array}$ & $\begin{array}{l}35 / 80= \\
0,4375= \\
43,75 \%\end{array}$ \\
\hline Social costs & $\begin{array}{l}65 / 90= \\
0,722222= \\
72,22 \%\end{array}$ & $\begin{array}{l}65 / 80= \\
0,8125= \\
81,25 \%\end{array}$ & $\begin{array}{l}65 / 85= \\
0,764706= \\
76,47 \%\end{array}$ & $\begin{array}{l}65 / 95= \\
0,684211= \\
68,42 \%\end{array}$ & $\begin{array}{l}65 / 80= \\
0,8125= \\
81,25 \%\end{array}$ & $\begin{array}{l}65 / 80= \\
0,8125= \\
81,25 \%\end{array}$ \\
\hline $\begin{array}{l}\text { Ability to create } \\
\text { traffic service }\end{array}$ & $\begin{array}{l}60 / 90= \\
0,666667= \\
66,67 \%\end{array}$ & $\begin{array}{l}60 / 80= \\
0,75= \\
75,00 \%\end{array}$ & $\begin{array}{l}60 / 85= \\
0,705882= \\
70,59 \%\end{array}$ & $\begin{array}{l}60 / 95= \\
0,631579= \\
63,16 \%\end{array}$ & $\begin{array}{l}60 / 80= \\
0,75= \\
75,0 \%\end{array}$ & $\begin{array}{l}60 / 80= \\
0,75= \\
75,0 \%\end{array}$ \\
\hline Other elements & $\begin{array}{l}20 / 90= \\
0,222222= \\
22,22 \%\end{array}$ & $\begin{array}{l}20 / 80= \\
0,25= \\
25,0 \%\end{array}$ & $\begin{array}{l}20 / 85= \\
0,235294= \\
23,53 \%\end{array}$ & $\begin{array}{l}20 / 95= \\
0,2105= \\
21,05 \%\end{array}$ & $\begin{array}{l}20 / 80= \\
0,25= \\
25,0 \%\end{array}$ & $\begin{array}{l}20 / 80= \\
0,25= \\
25,0 \%\end{array}$ \\
\hline
\end{tabular}

Further discussion involves the comparison of the characteristics of services in sea-borne passenger traffic that will have markedly high direct growth rates, namely the travel duration and the ability to create sea-borne passenger traffic service, with the characteristics having lower growth rates. Even though individual travel costs are not a characteristic that will have a very high growth rate, they will be compared with other service characteristics because gathered empirical data have confirmed that travelling costs are presently the most important characteristic of the transport service when choosing the mode of transport. Naturally, the comparison of other elements of the model using the same principle is also possible, but it will not be performed due to limited space.

When comparing travel duration with other characteristics of services in sea-borne passenger traffic, the growth rates of travel duration in relation to other service characteristics range from $63.16 \%$ to $75 \%$ (Figure 3 ).
Travel duration as a service characteristic in sea-borne passenger traffic generates the highest growth rates with respect to its ability to create sea-borne passenger traffic service (75 $\%)$ and other elements (75\%), which implies that the growth of importance of these characteristics will result from travel duration.

However, when indirect growth rates of other service characteristics in maritime passenger traffic are compared with travel duration (Figure 4), the highest growth rates are clearly achieved by social costs of transport ( $81.25 \%)$ and the ability to create sea-borne passenger traffic service (75\%). This means that the importance of these service characteristics most effectively contributes to the growth of importance of travel duration as the service characteristic essential for organising fast sea-borne passenger traffic routes.

When comparing the ability to create sea-borne passenger traffic service with other characteristics of services in sea-borne 


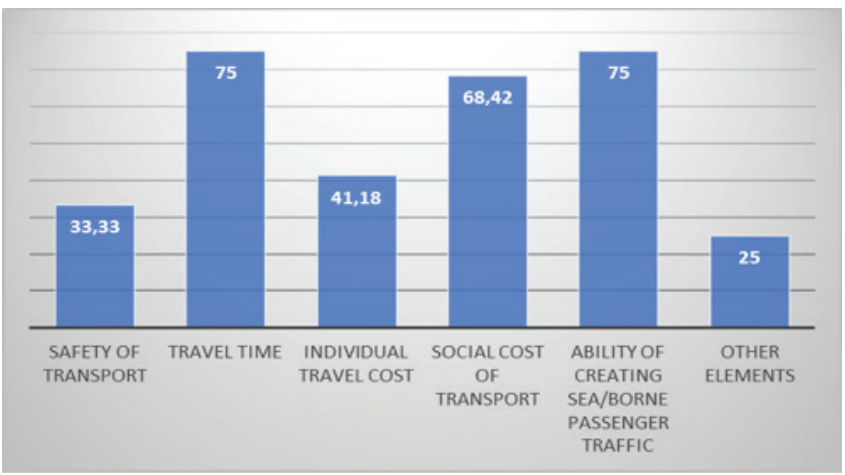

Figure 2.

Direct growth rates of the characteristics.

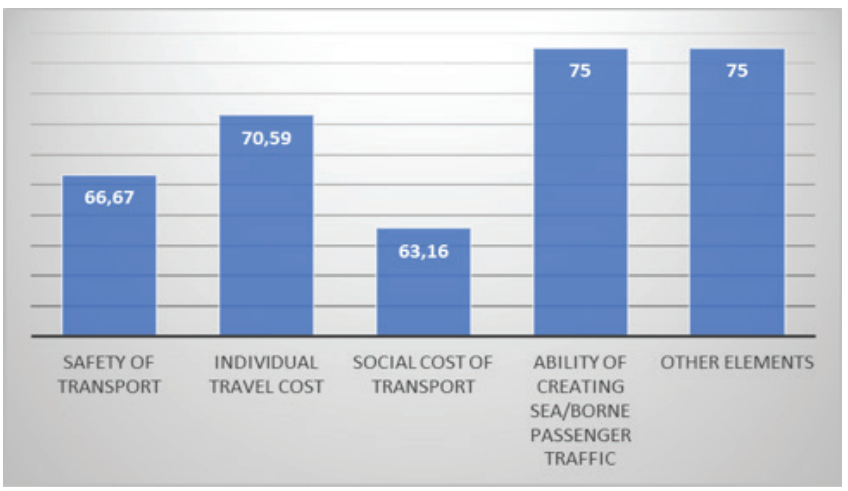

Figure 3.

Growth rates of travel duration in relation to other service characteristics.

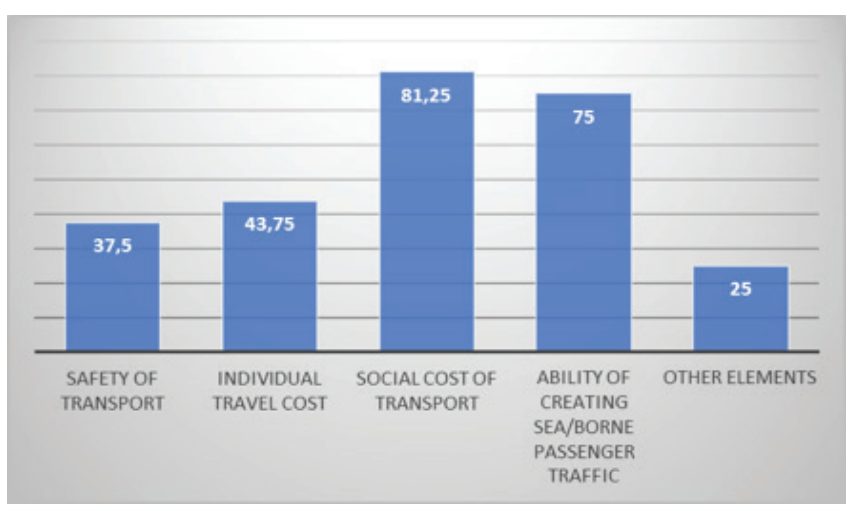

Figure 4.

Indirect growth rates of other service characteristics vs. travel duration.

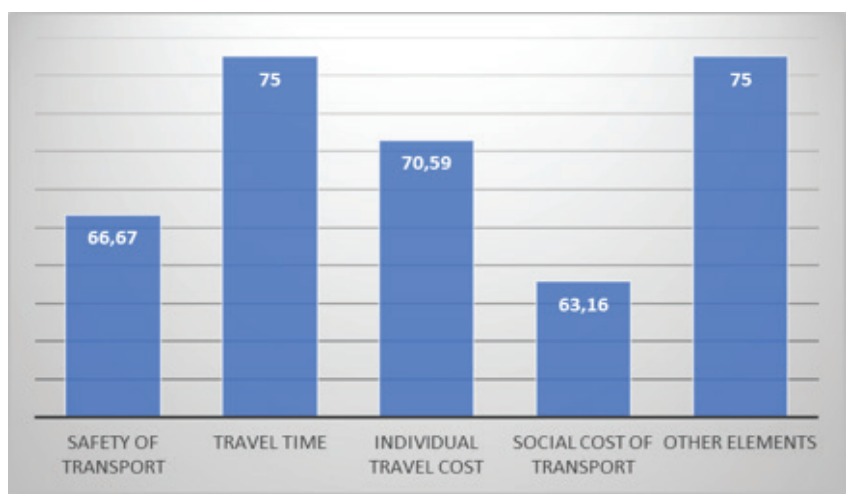

Figure 5.

Indirect growth rates of the ability to create sea-borne passenger traffic service in relation to other service characteristics.

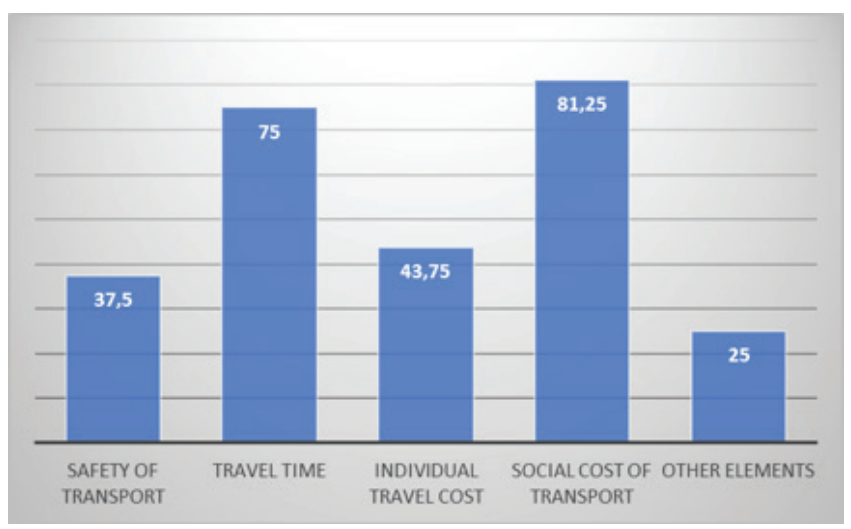

Figure 6.

Indirect growth rates of other service characteristics in comparison with the ability to create sea-borne passenger traffic service.

passenger traffic, growth rates range from $63.16 \%$ to $75 \%$ in comparison with other service characteristics (Figure 5).

The ability to create sea-borne passenger traffic service as a service characteristic in sea-borne passenger traffic has the highest growth rates when compared to travel duration (75\%) and other elements $(75 \%)$, which implies that the growth of importance of these characteristics will result from the ability to create sea-borne passenger traffic service.

However, when indirect growth rates of other service characteristics in maritime passenger traffic are compared with travel duration (Figure 4), the highest growth rates are clearly achieved by social costs of transport $(81.25 \%)$ and the ability to create sea-borne passenger traffic service (75\%). 
This means that the importance of these service characteristics most effectively contributes to the growth of importance of the ability to create sea-borne passenger traffic service as the service characteristic essential for organising fast sea-borne passenger traffic routes.

When comparing individual travel costs with other characteristics of services in sea-borne passenger traffic as model elements affecting the introduction of inter-city lines, the growth rates of individual travel costs range from $36.84 \%$ to $43.75 \%$. Their comparison with other service characteristics is provided in Figure 7.

When comparing indirect growth rates of other service characteristics in maritime passenger traffic with individual travel costs (Figure 8), it is obvious that social costs of transport (76.47 $\%)$ and the ability to create sea-borne passenger traffic service (70.59\%) have the highest growth rates.

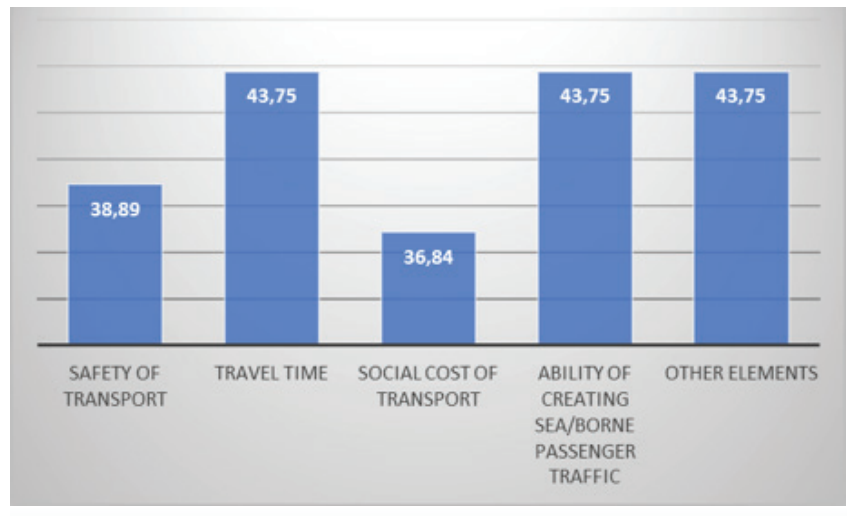

Figure 7.

Indirect growth rates of individual travel costs vs. other service characteristics.

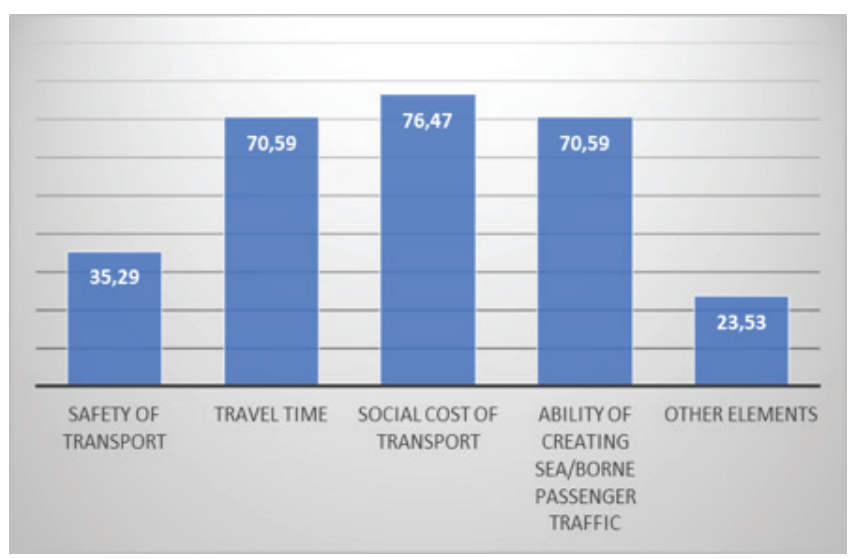

Figure 8.

Indirect growth rates of other service characteristics vs. individual travel costs.
This implies that the importance of these service characteristics most effectively contributes to the growth of importance of individual travel costs as a service characteristic essential for organising fast sea-borne passenger traffic routes.

\section{CONCLUSION}

The requirements for establishing fast sea-borne inter-city passenger lines in the Republic of Croatia arise from the need to redirect passenger traffic from overburdened road infrastructure to seaways. Maritime transportation offers a number of benefits as it is more environmentally-friendly, more cost-efficient, more reliable and safer than road transport. The introduction of new inter-city passenger lines would reduce overall transport costs since maritime infrastructure (fairways and seaports) already exists. However, this potential cannot be fully exploited without effective entrepreneurial ideas and projects.

The conducted research and valuation of the importance of the characteristics of maritime transport service for the period 2008-2025 have confirmed that all characteristics of sea-borne passenger traffic will produce significant growth rates. This will allow Croatian shippers to cope with foreign competitors and competitors operating in other modes of transport. The direct growth rates of service characteristics in maritime passenger traffic as model elements for the organization of inter-city lines have been divided into two essential groups. The first group consists of the Ability to create sea-borne passenger traffic service and Travel duration, both having direct growth rates of $75 \%$, and Social costs of transport, with the growth rate of $68.42 \%$. The impact of these characteristics can be assessed as markedly strong. The other group of characteristics includes Individual travel costs, with the growth rate of $41.18 \%$, Transport safety, with the growth rate of $33.33 \%$, and Other elements ( $25 \%)$. The impact of these characteristics as model elements for the organization of inter-city sea-borne passenger lines was assessed as acceptable, with strong prospects for further enhancement and validation.

\section{REFERENCES}

Benvenuto, G., et al., 1996. Environmental impacts of land and maritime transports in urban areas. 2nd International Conference on Urban Transport and the Environment (Urban Transport 96), Barcelona.

Chen, Y., et al., 2017. Modeling service time reliability in urban ferry system. Modern Physics Letters B 31(26), pp.1750242. Available at: http://dx.doi.org/10.1142/s0217984917502426.

Jurčević M., Madunić P., Tolušić I., 2006. Relations between transport and tourism Croatia's possibilities, Promet - Traffic \& Transportation 18(5), pp. 369-378.

Kovačić, M., Milošević, T., 2016. Interdependence of Transport and Tourism, Pomorski zbornik 52, pp. 99-111.

Krpan, LJ., Maršanić, R., 2004. Značenje i uloga hrvatskoga prometnog sustava u europskim prometnim tokovima. Suvremeni promet 24(1). 
Moise, I.G., 2015. Maritime security strategy of the EU towards global maritime domain and safe. International Conference on Law between Modernization and Tradition - Implications for the Legal, Political, Administrative and Public Order Organization, Bucharest, pp 732-743.

Padjen, J., 2002. Determinante prometne politike Hrvatske. Ekonomski pregled 53(1-2).

Pupavac, D., 2009. Načela ekonomike prometa. Rijeka: Veleučilište u Rijeci.

Pupavac, D., Plazibat, V., Krčum, M., 2015. Modelling Transport Demands in Maritime Passenger Traffic. Naše more, 62(1), pp.8-12. Available at: http://dx.doi.org/10.17818/nm.1.2.2015.

Plazibat, V. et al., 2015. Tools of Quality in Determining the Characteristics of Services in Maritime Passenger Transport. Naše more, 62(2), pp.53-58. Available at: http://dx.doi.org/10.17818/nm/2015/2.2.

Sabolović, R., 2002. Brzobrodske linije kopno - otoci - doprinos razvoju turizma. Suvremeni promet 1-2.
Serap, I. et al., 2007. Effects of Globalization in Maritime Transportation, 8th International Conference on the Mediterranean Coastal Environment MEDCOAST 07, Vol 1-2, pp. 447-453.

Stojanović, D., 1990. Ekonomsko matematički metodi i modeli, dodatak: matrica rasta, Beograd: Univerzitet u Beogradu.

Zelenika, R., Pupavac, D., 2008. Menadžment logističkih sustava. Rijeka: Ekonomski fakultetu u Rijeci.

Zelenika, R., 2010. Ekonomika prometne industrije. Rijeka: Ekonomski fakultet u Rijeci.

UN World Tourism Organization, 2011. Tourism highlights. Available at: https:// www.e-unwto.org/doi/book/10.18111/9789284413935 